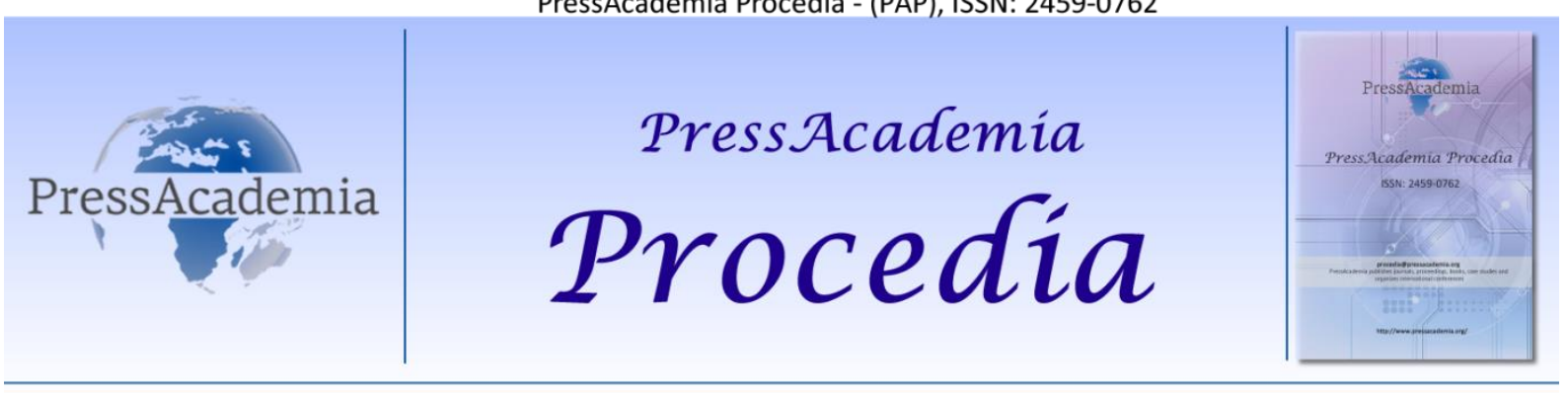

2nd World Conference on Technology, Innovation and Entrepreneurship

May 12-14, 2017, Istanbul, Turkey. Edited by Sefer Şener

\title{
RELATION BETWEEN CONTEMPORARY FURNITURE AND TECHNOLOGY
}

\section{DOI: 10.17261/Pressacademia.2017.547 \\ PAP-WCTIE-V.4-2017(39)-p.300-305}

\section{Isil Ozcam}

Mimar Sinan Güzel Sanatlar Üniversitesi, isil.ozcam@msgsu.edu.tr

\begin{abstract}
Furniture, the indicator of the identity, belief and prestige, being always in interaction with person's life, is in addition to its function, a meaning carrier and communication object. Furniture, which were previously manufactured due to practical, aesthetic and status based needs, but started to be used deliberately in order to transmit messages by the beginning of the last century; has reached a broad meaning content and diversity by the influence of the technological developments at present, too. Contemporary artists and designers deem this form as a tool which transmits thoughts, philosophy, ideologies, statements, ideas, feelings and can at the same time be used as an application area where experimental manufactures, composite materials, scientific researches, contemporary design and production methods can be tried out.
\end{abstract}

Keywords: Furniture, production methods

JEL Codes: N25, M40, 010

\section{FURNITURE DESIGN THROUGH HISTORY}

Furniture design and production has significantly diverged its direction by the social developments broke out at the beginning of the $20^{\text {th }}$ century; and the handicraft based productions were replaced by designs, shaped by rationalistfunctionalist principles and serially produced, in parallel with the materials and new production technologies introduced by the industrialization process. The modernism period are the years, where designers and architects had started to reflect their thoughts, philosophies, feelings, ideologies via the furniture form. And in the 1980s, when the principles of modernism reversed, ornamentalism revived; and independent designers started to produce one-off and limited quantity furniture. The influence of the post-modernist philosophy, felt in every field of life, has supported symbolism and the use of metaphors, and outlined the communication feature in design. Designers, working in this field, were able to express themselves more freely by their designs, where wide forms and materials were used since they are not subject to serial production limitations.

Figure 1: The 'Kitchen Chair', Made By Tom Dixon In 1987 By Using Frying Pans, Pots And Ladles Has Been Sold To High Prices in The Upcoming Years.

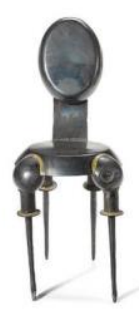

As of the 1990's have mass design trends in the design world started to be replaced by individual approaches. Today is the furniture form being increasingly more often used by the designers and artists as an expression of a thought - as a communication tool. These works between art and design, which sometimes indicate a philosophy, aesthetic opinion or identity, and sometimes as an experiment on materials, can be viewed in galleries, art exhibitions, museums, auctions, biennales and private collections. It is possible to see at these designs; utilizing the expression methods of the past and 
present, traces of postmodernism, the political art of the $20^{\text {th }}$ century, modernist movements, surrealism, popular art, expressionism and ethnic elements. Each designer follows his or her own ideas and inspiration sources within the contemporary furniture perception, which has its foundations in the communication prioritizing and experimental approach; the fund of knowledge, experience, political opinion and personality attributes gain importance at this point. The designer, who forms his or her furniture with his or her distinctive interpretations, indicators and symbols, is thus able to reveal his or her own identity, to achieve different design definitions, to attract the attention in the global market and/or to give social messages. The messages aimed to be transmitted are concretized on the designs within a structure decorated with symbols; the philosophic and artistic creation processes combine with the style of the designer and define new meaning codes. The words of Philippe Starck in an interview that "he wouldn't make designs for design but makes designs in order to talk to people" is sampling this situation. References are made to definite objects, beings, notions or facts with the product's form; deliberate meanings are loaded on forms by means of metaphors; a story is told with the design. Whilst the role of metaphors at art furniture is to transmit a message or a philosophy; their role at sales purposed furniture is to convert the object into an understandable, interesting and known status by the transmitted information.

Figure 2: The Design of Iskos-Berlin, Named 'Bunny Chair', Where A Bunny Figure And A Sitting Element Form Was Combined, In 2012.

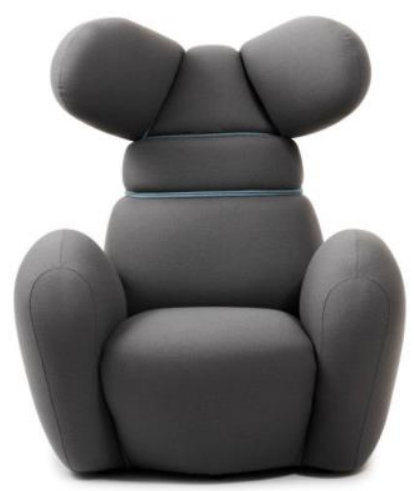

Figure 3: Ron Arad's Design Named 'Looming Lloyd’ Is Formed With The Metaphor Of “A Human Leaning Forward And Seeming To Start Walking".

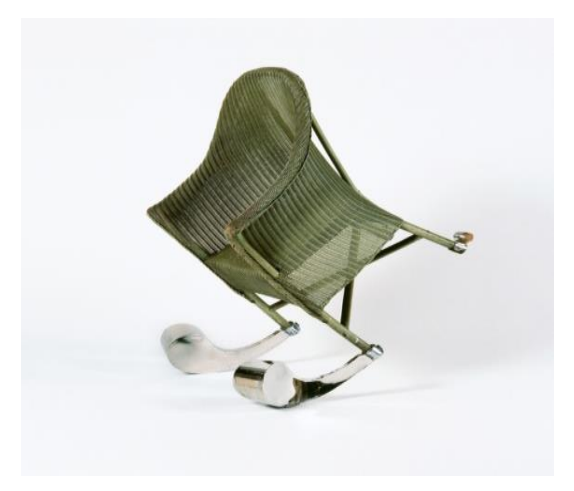

\section{CONTEMPORARY FURNITURE}

If the aesthetic program of the furniture evokes the artistic one, then the object can combine with the notional symbols and become an installation. In this case philosophic design objects are accepted as a part of art (Uzunarslan, 2010). A. Payne has named such works between design and art as "Design Art"; he aimed to attract the attention on that how indistinct the borders between design and art became, how they interpenetrated and joined in a common language when he first introduced this definition in 1999 (Lovell 2009, p. 111). And some researchers have named private/limited produced contemporary furniture as "New Design", separated them from serial production.

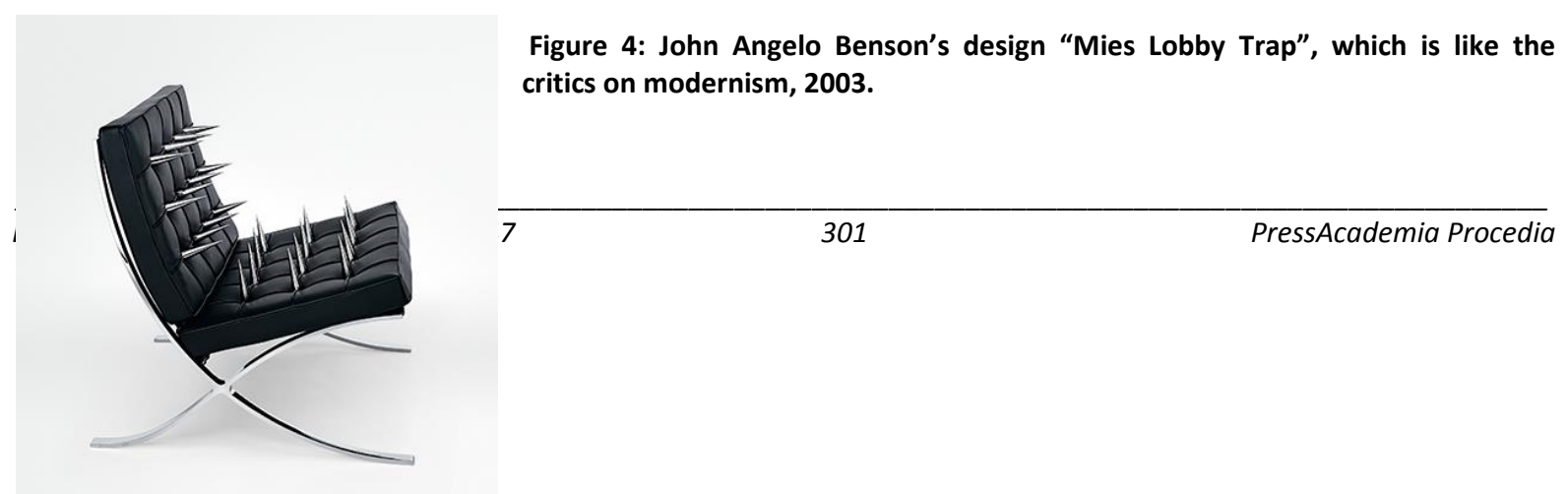


Contemporary furniture designer prefer special manufactures to serial production; thus, they are able to express their ideas more free with an independent form and material option. Special and limited produced furniture with individual efforts, as a result of cooperation with companies and galleries are designs, which there is no obligation to be suitable for industrial production, the designer can establish his or her own program and there is no consideration with regards to sales and practical function. Even if these don't address to wide user masses, they contribute to the development of the form language on the furniture. And serial production furniture have been produced industrially for wide masses by several companies. The function and user factors are involved in these designs manufactured with the sales priority; in this case designer acts pursuant to a program determined by the company and requested from him/her. In both situations designers may head to various symbols as an identity determinant or to attract the attention; at this point, she or he can benefit from different disciplines, interpret traditions, historical symbols, different existing cultural elements and create new design definitions for utilization habits. And the reason of preference of such furniture by the user can be correlated to status, authenticity and individualism desire, appreciation of the designer's style/philosophy, the desire to gain new experiences and aesthetic preferences (Özçam 2013). The economic status of the user is a factor with regards to the preference of contemporary furniture, the carriers of messages related to identity and life style, too.

Figure 5: Wu Yu-Ying, who benefited from the visual and sensual features of polyurethane foam material, wanted to offer a different experience with his design named "Breathing Chair" to the user.

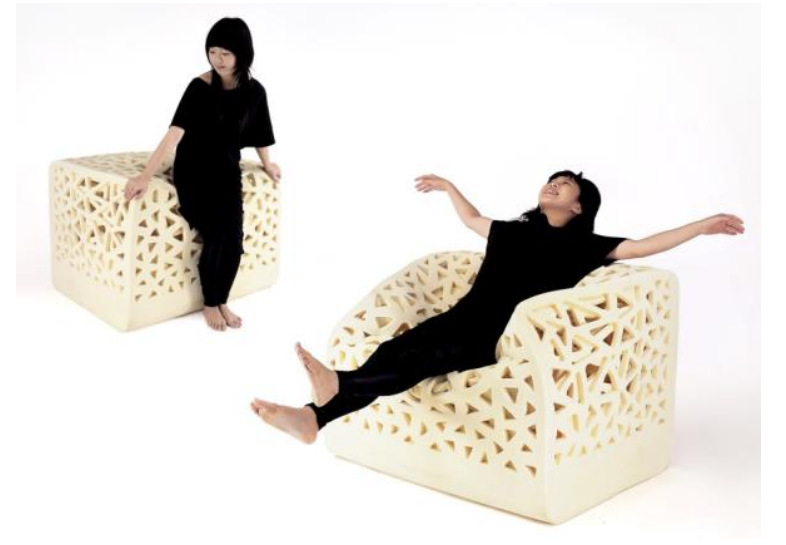

\section{CONTEMPORARY FURNITURE AND TECHNOLOGY}

Another important factor for the shaping of furniture and the growth of the contemporary furniture market is developments in the fields of technology and information and communication. The rapid progressing technology in parallel with the scientific developments brings also a new content and shaping approach with it and turns this form into a subject of experimental productions. While the CAD/CAM technologies mediate with increasing computing and production capabilities and between the idea and the final product during the design process and also it increases and enriches the physical-notional skills/capacity of the designer and provides a more independent working environment. The usage of computers during the design and production stages influences the furniture also in structural sense by facilitating the design of sensitive forms and complex geometries which were impossible in the past. 
Figure 6: Patrick Jouin Converted The Numeric/Linear Shape Language Into Three Dimensional Models In His Designs Named "Solid T1" And "Solid Chair", Which He Produced Only Thirty Pieces Of By Using Epoxy Resins With The Stereolithography Technique.
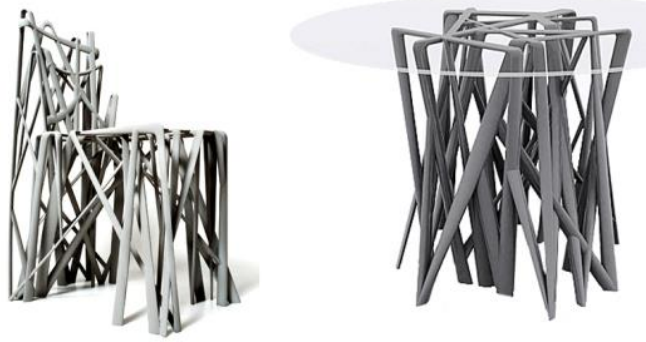

New computer software, developed considering the parametric/algorithmic design and the growth principles of the organisms in the nature, has allowed the usage of topographic forms, skeleton systems, natural formations, dynamic forms and structure systematic, fractal geometries at furniture designs and enabled to the possibility to create an irregular and incidental style language.

Figure 7: Mathias Bengtsson's design "Cellular Chair" is created by using a program, imitating the human cell formation and a three dimensional modeling technique.
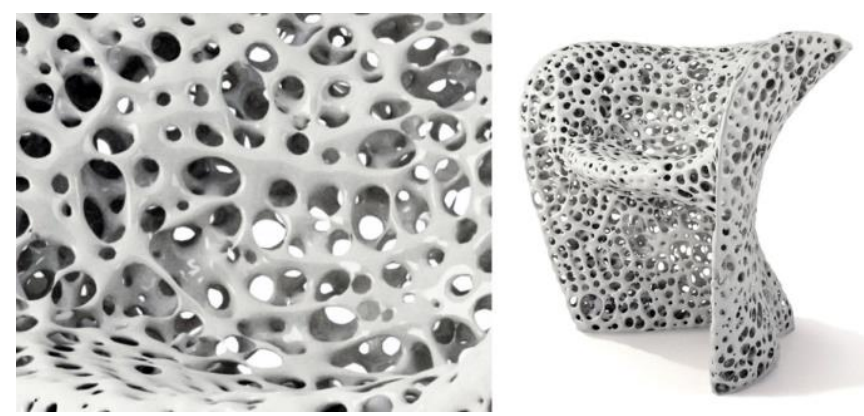

The opportunities offered by present technologies, rapid developing animation and modeling technologies in virtual reality make changes on the structure, character and manufacture of the furniture; concepts such as personal experience and movement, which is a part of design, contribute to experimentality, expression and improvisation strength to designs. All of these gives the message that custom tailored designs and alternative design processes will get ahead standard productions in the future.

Figure 8: In The "Front Design Sketch Furniture" Series, Furniture Is Created By The Conversion Of The Hand Movement In The Air Made With A Special Pen, Which Are Recorded With A Movement Capturer Into Three Dimensional Computer Models And Production With The Rapid Prototype Technique.

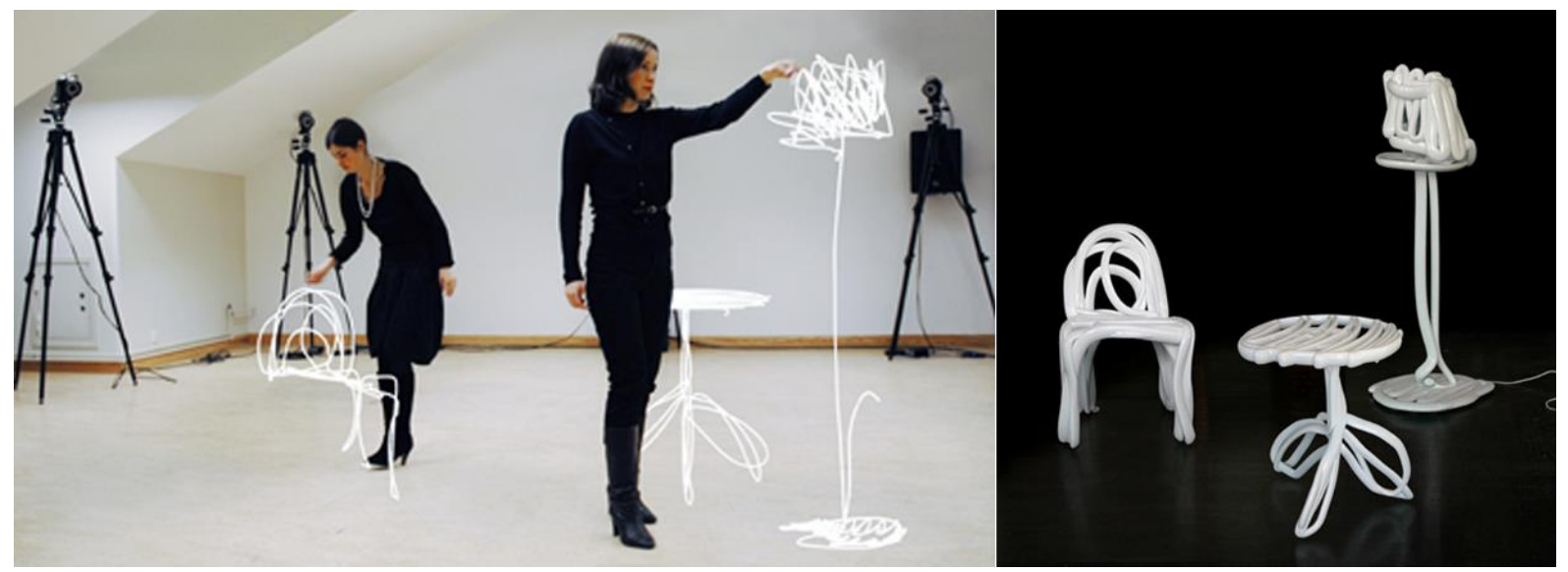

Another influence of numeric technologies on furniture style is forms which entered into our lifes with the drawing programs used on the computers. Today many designers are modeling their furniture with two dimensional and three dimensional programs; and this causes that they get influenced by the styles offered by the virtual environment during the 
symbol searching stages. Different line-surface indications (wireframe, pixel, grid system) and commands (lathe, extrude, boolean) are some of the inspiration sources for the designer in the computer style language. As long as the limits are removed in the production, also stylistic definitions increase and liberalize and experimental approach develops.

Figure 9: Sebastian Brajkovic Refers To Both Furniture Styles In The Past And To The "Lathe" Form, Which Is A Computer Program Command In "Lathe" Series.
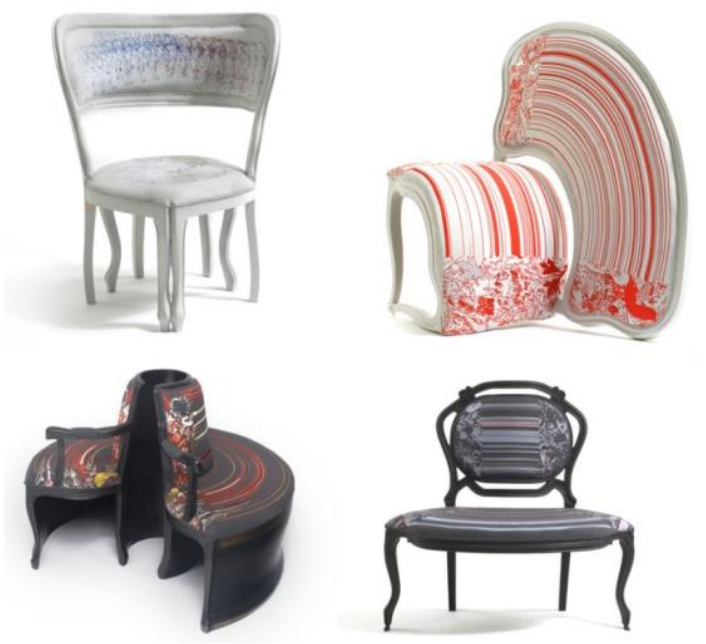

Individual shares increase by gradually increasing enrichment of the communication tools in visual and auditory aspects and the validity periods of the developed strategies in order to come to the forefront in the platform called virtual environment where a great majority of the society is involved into gets gradually shorter and the trend to the new one is obliged. Companies and designers, who aim to reach the masses, are using the Internet as an promotion and advertisement tool. This environment, which is in a continuous change and development, directs the designers to create competition prioritized designs with high communication value. The universalization of the communication language developing between the designer and the user increases the interaction between the individuals/societies. The globalization as a result of the increasing interaction brings the original among the products, of which everywhere a similar can be found, to the foreground. Another result of the technological developments is composite materials, which offer new liberties. Features such as developing material options, flexibility, strength, easy shaping offer broad opportunities with regards to establishing a notional and stylistic frame to the designers. Correspondingly, designs can be are easier associated with communication imagines like symbols-metaphors.

At the same time, thanks to nanotechnology materials, capable to perceive the environment and adopt to it, the bonds and interactions between objects and human gain new meanings.

Figure 10: "Noumenon Armchair", a design by Carl de Smet, which heats up with electrical energy, expands and reaches a form that refers to the shape of a bone.

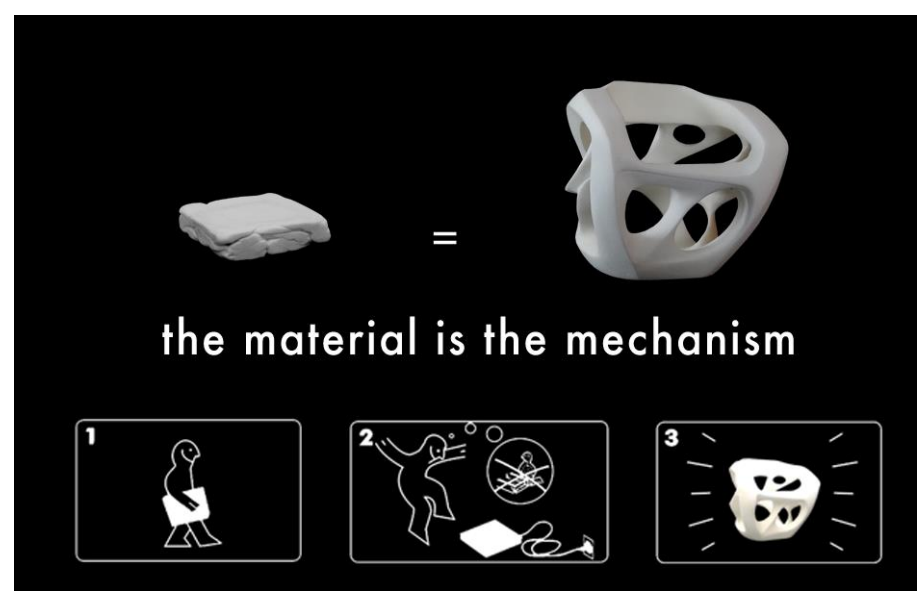

Even if industrial and technological developments contribute to the functionality at present, the communication purposed design phenomenon continues by getting stronger; individuals prefer furniture, which defines their life styles, they establish a mental bond and find them aesthetic. Downey has interpreted the increase of the interest towards these works between 
art and design as: "Furniture is a new area, where people can experience arts. The reason of the interest for such works is that people find furniture more understandable than abstract art (Downey 1992, p. 14).

\section{CONCLUSION}

It is seen that depending on the differentiation and communication need required at present the contemporary trends in furniture increase, being out of context of the practical/functional usage of furniture, they convert into an object, indicating desire, thought and identity, loaded with cultural symbols. Furniture find their place in the market by coming to the forefront by its brand or the signature of its designer; users or collectors tend to products, which they deem to be aesthetic/valuable, and status prioritized usage, symbolic and aesthetic function start to get increasingly more important. Correspondingly, sometimes furniture are programmed with symbols reflecting the designer's identity, and sometimes ads communication objects which are able to offer the user infinite alternatives with regards to practice and aesthetics by symbols meeting the individual preferences. Contemporary designers interpret the style language of the furniture and communicate their statements and they seek for new ways to express themselves with experimental designs and by developing production techniques. Technological developments make it possible to produce furniture, which is not able to produce in the past and change their form and structures. Symbols are moving away from the trimming dimension; the furniture converts into a symbol entirely with its style, material, dimension and pattern. It is thought that in the near future furniture, with relation to technology will meet the change requests further. Furniture will be a tool for the humanenvironment interaction from structural construction to geometrical gains and from technical gains to innovations, provided by the nano-technological opportunities to the design.

\section{REFERENCES}

Uzunarslan, H.Ş., 2010. 'Aesthetic Content in Experimental Design', The Eighteenth International Congress of Aesthetics: Diversities in Aesthetics", Beijing, China

Lovell, S., 2009. Limited Edition, Prototypes, One-Offs and Design Art Furniture, Birkhauser Verlag AG, Basel.

Özçam, I., 2013, Biçim Dili İle İletişim Ekseninde Mobilyanın Sembolleşmesi Ve Günümüz Mobilyasının Sembolleşmesinde Rol Oynayan Sosyolojik Ve Teknolojik Etkenler (Symbolization of Furniture on The Axis of Form Language and Communication \& Sociological and Technological Effects on Symbolization of Today's Furniture) Unpublished Doctorate Thesis, Interior Design Department, Mimar Sinan Fine Arts University.

Downey, C., 1992, Neo Furniture, Thames \& Hudson Ltd., UK 